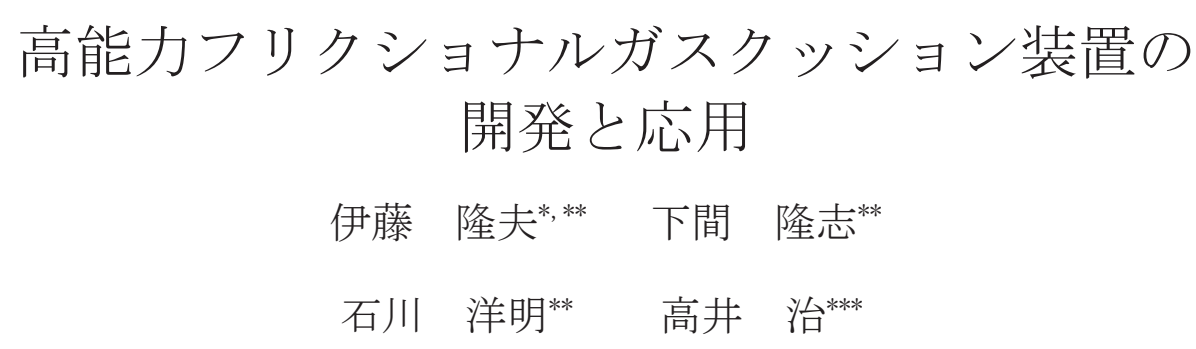

\title{
Development and Application of High-Performance Frictional Gas Cushion Device
}

\author{
Takao ITO*,**, Takashi SHIMOMA**, \\ Hiroaki ISHIKAWA ${ }^{* *}$ and Osamu TAKAI***
}

(Received on August 29, 2018)

\begin{abstract}
Recent ultrahigh-tensile-strength steel sheets have become indispensable for improving fuel economy through their incorporation into skeletal parts of automobiles to reduce the weight. To enable the forming of ultrahigh-tensile-strength steel sheets, a high-performance upper cushion is indispensable. The developed high-performance frictional gas cushion device applies as cushion force by frictional force generated by sliding between metal parts of the shaft parts and the hole parts having interference. Frictional cushion force mechanism was added to the upper piston shaft portion of the gas cushion device. In this apparatus, in addition to the repulsive force (gas cushion force) generated by the gas when the piston is pushed into the cylinder, frictional force (frictional cushioning force) due to interference between the inner surface of the cylinder and the outer surface of the piston shaft can be obtained. Therefore, it is possible to obtain a higher cushioning force than that with the conventional gas cushioning apparatus, which generates cushioning force only by the repulsive force of the gas.
\end{abstract}

Key words: friction, surface treatment, interference fit sliding, gas cushion, die cushion device, high durability.

\section{1. 緒 言}

産業機械の多くに使用されているばねの代用として，ガ ス封入式のガスクッションが知られている. ガスクッショ ンは,コイルスプリング等と比較して高荷重（高クッショ ン力）であり，省スペース化を図りやすいといった特徵が ある. 近年の高張力材料のプレス加工や板鍛造に使用され るダイクッションには, より高いクッションカが求められ ている.しかし, ガスクッションでは高張力鋼板の成形に は能力が足りないことがある．所望のクッション力を得る ために，ガスクッションを多数配置することも考えられる が，金型の剛性低下による精度不良を起こす場合もある.

\footnotetext{
* 関東学院大学大学院総合工学専攻 (材料·表面工学専修)

于250-0042 小田原市荻窪 1162-2

Doctoral Course in Interdisciplinary Engineering,

Graduate School of Engineering, Kanto Gakuin University,

1162-2 Ogikubo, Odawara 250-0042, Japan.

E-mail:itotaka@aida.co.jp

** アイダエンジニアリング(株) 開発本部

厂252-5181 相模原市緑区大山町 2-10

Research \& Development Headquarters, Aida Engineering, Ltd.,

2-10 Ohyama-cho, midori-ku, Sagamihara 252-5181, Japan.

*ook 関東学院大学工学研究科, 材料・表面工学研究所

干250-0042 小田原市荻窪 1162-2

Materials and Surface Engineering Research Institute, Kanto Gakuin University, 1162-2 Ogikubo, Odawara 250-0042, Japan.
} そこで, コンパクトで高いクッション力が得られるダイク
ッション装置の開発が望まれている.

\section{2. 技術の動向}

自動車産業では然費向上の施策として, 車体骨格の軽量 化が必須となっており, 超高張力鋼板の成形課題の克服が 急務となっている. 今後の超高張力鋼板の市場への展開に おいて, 工法の転換が必要不可欠である.

従来の車体骨格成形工法の金型構造と一工程内の成形過 程を Fig. 1 に示す. 従来工法では Fig. 1 のように, 上型の ダイと下型のしわ押さえプレートで材料を挟み込み曲げや 絞り加工を開始し，下死点にて上型のダイと下型の成形パ ンチの隙間に材料を挟み込み，製品の上面にあたる部分の 形状の成形を完了する，絞り加工する場合，成形時に下部 ダイクッション力にて, しわ押さえプレートに背圧を与え, ダイと共にワークの周縁を挟み込み, 材料の流入を制御し, しわや割れの抑制を行っている ${ }^{1 ， 2)}$. この時，上部ダイク ッションは, 使用されていない.

SPCC 材のような一般鋼材や引張強さが $270 \mathrm{MPa}$ 程度の 鋼板では成形可能であった形状でも, 同一金型で $1470 \mathrm{MPa}$ 級の超高張力鋼板の成形を行うと，曲げや絞り加工時に, 
材料強度によって上型と下型の空間内に, 材料が張り出し 形状に変形する. 上型ダイの下降が進行し, 上型と下型の 空閒が減少すると, 張出した材料があまり, しわとして成 形される。このしわのため, 製品形状に成形することが出 来ず，下死点まで上型を下げると金型を破損させてしまう 場合もある。

Fig. 2 に従来工法の金型で超高張力鋼板を成形した時の 材料の状況を示す.

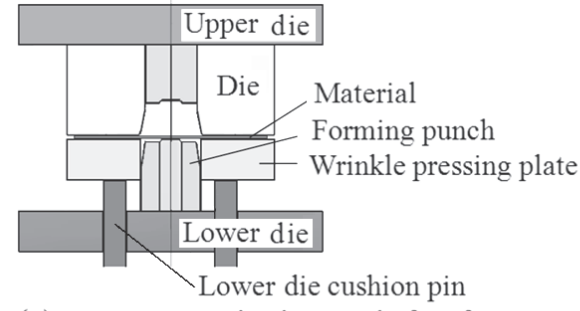

(a) During upper die descent, before forming

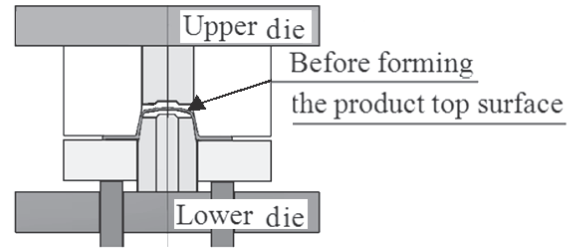

(b) Before bottom dead point, forming in progress

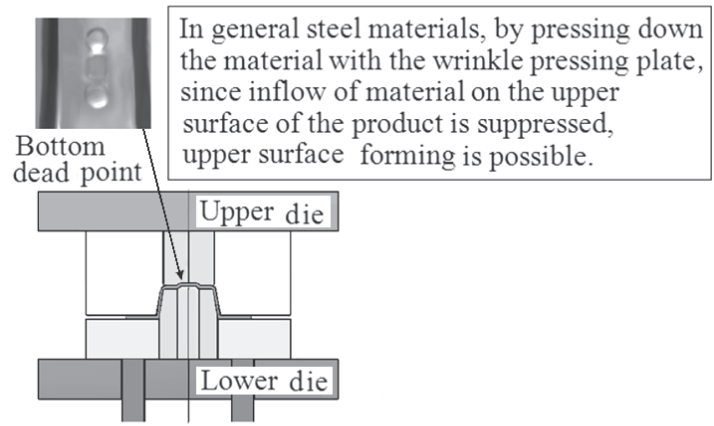

(c) At the bottom dead point, product upper surface forming is completed

Fig. 1 Die structure for conventional method

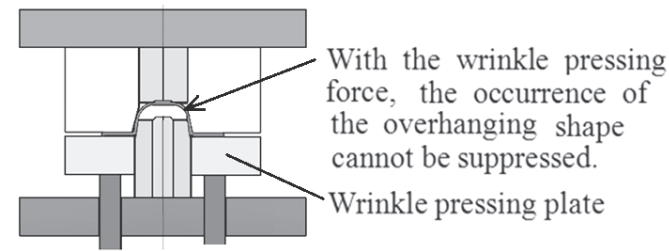

(a) Before bottom dead point, forming in progress

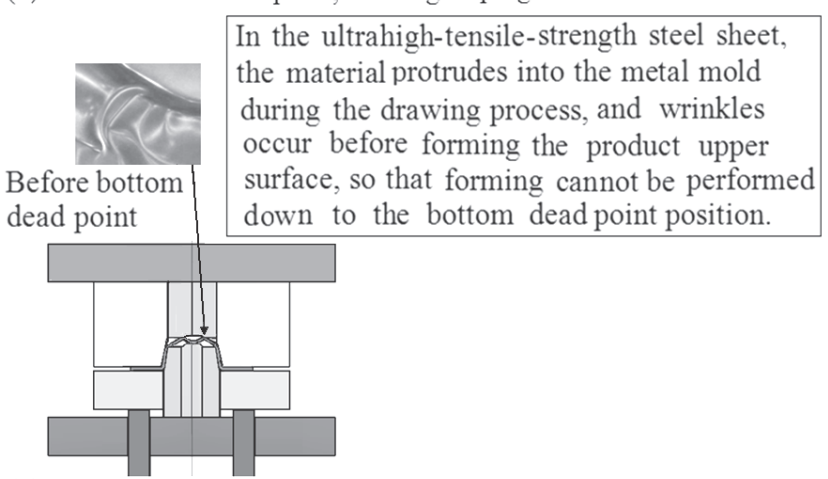

(b) Forming cannot be performed down to the bottom dead point position

Fig. 2 Ultrahigh-tensile-strength steel sheet drawing by conventional die method

\section{3. 開発の目的，手段}

超高張力鋼板を成形するには，まず曲げや絞り加工時に 発生する頂点部材料のあまり発生を抑制し，曲げや絞り加 工が開始される前に，製品の上面にあたる頂点部の成形を 上部ダイクッション力にて完了させる，そのまま上部ダイ クッション力にて上面成形部を拘束し続けながらしわの発 生を抑制し，曲げや絞り加工を行う工程に工法転換するこ とで可能になる. Fig. 3 に上部成形を上部ダイクッション にて曲げや絞り成形加工前に開始する新工法の金型構造を 示す.

新工法のように製品の上面にあたる部分の成形を先行成 形寸る場合，プレス機械のスライドに新たに上部クッショ ン装置を設備しなければならない。しかし，製品毎に成形 に必要なダイクッション能力, ダイクッションピン位置が 異なるため, 汎用機としてプレス機械のスライド部にダイ クッション装置を設備すると，ダイクッションピン位置が 限定され，ピン位置の共用化が必要となり，製品毎の最適 な金型設計が困難になる。この問題を解決するために，油 圧ダイクッション装置を上型に内蔵する手段も考えられる が，金型毎に油圧シリンダ部の製作が必要であり，金型の コストアップと油圧ユニットとの配管作業等の段取り時間 によるコストが発生する。 また，ガス封入式のガスクッシ ヨンをダイクッションとして使用することも考えられるが, ガスクッションの初期設定圧力は $15 \mathrm{MPa}$ 程度である. 超 高張力鋼板の上面成形に必要な初期能力を金型に内蔵でき るようにコンパクト化したガスクッションで得るためには, $25 \mathrm{MPa}$ 程度の初期圧が必要となる。このため, 従来のガス クッションでは初期能力が足りず，所望のクッション力を 得るために，ガスクッションを多数配置することが必要と なる。しかし，能力を上げるためにシリンダ外径の大きな ものの使用や多数配列すると，金型剛性の低下や最適箇所 に配置できない等の問題もある.さらにガスクッションは, ストロークにより封入されている窒素ガスの体積が減少す るため, 下死点でクッション能力が最大荷重となったとき, 絞り成形時の製品割れの原因となる場合もある.

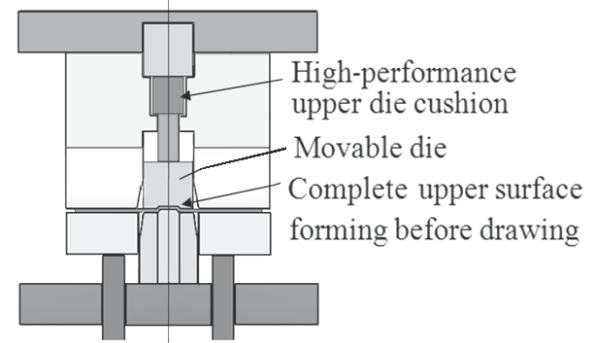

(a) Before bottom dead point, complete upper surface forming

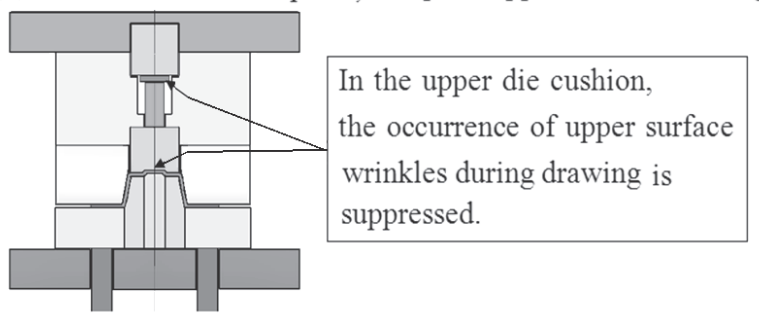

(b) Bottom dead point

Fig. 3 Die structure for new construction method 
以上の問題を解決するために, ストローク開始時点から 高いクッション力が得られ, ストロークによる能力増加の ないクッション装置の開発が必要である.

一般にガス封入式ガスクッションでは，パッキンシール の材質は合成ゴムや合成樹脂なので，初期充填圧力は 15 $\mathrm{MPa}$ 程度である。この圧力をさらに上げて高能力化を考え ると，ストローク時の増圧力でのパッキンシール部の耐久 性やシール性，増圧による能力増加の問題がある.

高負荷荷重用に開発した高能力フリクショナルガスクッ ション装置は, 締め代のある軸部品と穴部品との金属同士 の摺動により発生する摩擦力を応用し, 上部ピストンシャ フト部に摩擦力クッション機構を付加したものである. ピ ストンがシリンダへ押し込まれる際に，ガスによる反発力 （ガスクッション力）に加えて, シリンダの内面とピスト ンシャフトの外面の締り嵌めによる摩擦力（摩擦クッショ ン力）が得られる。 そのため, ガスの反発力のみでクッシ ヨン力を得ようとする従来のガスクッション装置に比べて, 高いクッション力を得ることができる. Fig. 4 に初期能力 仕様 $200 \mathrm{kN}$ の一般のガスクッションと, 同一能力のフリク ショナルガスクッションの大きさ比較を示す.

Initial load specification: $200 \mathrm{kN}$
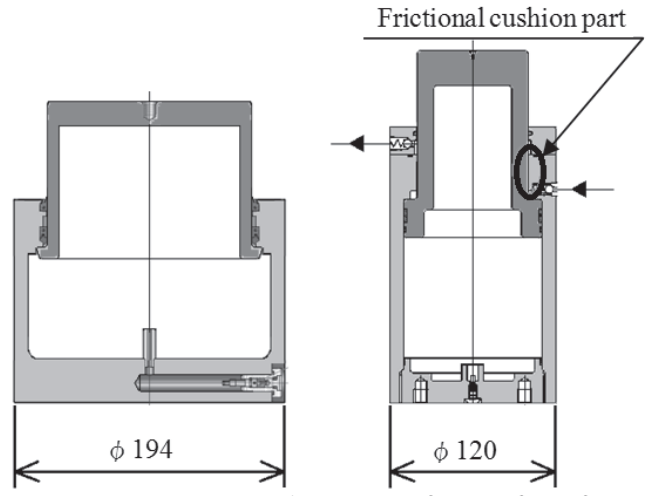

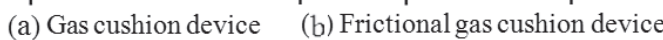

Fig. 4 Comparison of sizes of devices with same capacity

\section{4. フリクショナルガスクッション装置の課題}

フリクショナルクッション機構部は, 締り嵌めによる発 生面圧と摩擦係数により生まれる摺動抵抗をクッション力 として利用した技術であり，摺動熱によるかじりや焼付き， 摩耗の進行等の克服しなければならない技術課題があった.

ガスクッションと摩擦力を併用したフリクショナルガス クッション装置で確保しなければならない必須条件は,

(1) 焼付きの発生を抑えられること

(2) 高寿命であること

（3）負荷能力が安定していること である。

\section{5. 課題解決の手段}

嵌合部の摩擦係数を安定化させ, 摩擦ダイクッション部 の長寿命化を図るため, 面粗度と摺動時の摩擦係数, 及び 面粗度とかじりの有無についての予備実験を行った。実験 は，直径の $0.1 \%$ の締め代とし，ピストンおよびシリンダ の面粗度をそれぞれ Ra 0.03, Ra 0.08, Ra 0.10 Ra 0.12, Ra
0.18 どうしの組み合わせにして, 能力 $250 \mathrm{kN}$ の油圧プレス にて摺動テストを行った。 その結果，クッションピン及び ピンホルダそれぞれの面粗度を Ra $0.03 \sim 0.1 \mu \mathrm{m}$ に仕上げ ることで, 摩擦係数を安定化させ, クッションピンやピン ホルダの表面平滑性を損なうことなく，かじりの発生を抑 制できることを見いだした。ささら，焼き付きを生じさせ ないためには, 冷却と潤滑が必要不可欠であり, シリンダ 側に油溝を設けて，潤滑油による冷却及び潤滑を行った。 また，摩擦係数の低減を図るため，ピストンシャフト側に はラッピング後, 低温 $\mathrm{TiC}$ (炭化チタン) コーティング処 理を，シリンダ側にはラジカル窒化処理を施した.

摩擦クッション力 $F$ は, 嵌合部に発生する面圧 $p$ と, そ の面圧が作用する面積 $S\left(=\pi \times D_{1} \times L\right)$ と，嵌合部の金属 間の摩擦係数 $\mu$ との積 式（1）によって算出される.

$$
F=p \times \mu \times\left(\pi \times D_{1} \times L\right)
$$

また，嵌め合いにおける締め代 $\delta$ と, 発生面圧 $p$ の関係 は式（2）で示される ${ }^{3)}$.

$$
p=\frac{\delta}{D_{1}\left\{\frac{D_{0}^{2}+D_{1}^{2}}{E_{1}\left(D_{1}^{2}-D_{0}^{2}\right)}+\frac{D_{1}^{2}+D_{2}^{2}}{E_{2}\left(D_{2}^{2}-D_{1}^{2}\right)}+\frac{v_{2}}{E_{2}}-\frac{v_{1}}{E_{1}}\right\}}
$$

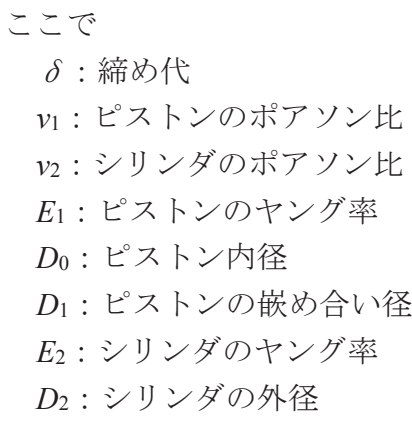

である。

摩擦係数 $\mu$ はピストンが動いているときは動摩擦係数が 採用され，静止している状態から動き出すまでは静止摩擦 係数が採用される。また， $L$ は嵌め合い長さ（軸方向）で ある。

ガスクッションは，ピストンの押し込みに伴ってクッシ ヨン力が増加する. 特に小型化を図ったものについては, 押し込み量に対するクッション力の増加率が大きい. クッ ション力が大きく変わると, 例えばワークの押え力が不適 切となってワークの割れや亀裂の原因となる. フリクショ ナルガスクッション装置では, フリクショナルクッション 機構部のピストンシャフトがシリンダ内から外に向かって 縮径していれば，ピストンシャフトの押し込みに伴い，締 り嵌めによる摩擦クッション力が減少する。 そのため, ピ ストンシャフトの縮径具合によりガスクッションカとフリ クショナルクッションカとの和で, クッション力の増加率 を小さくしたり，無くしたり，また反対にクッション力を 減少させることもできる. Fig. 5 に締り嵌めによる摩擦ク ッション力が減少する概念図を示す.

シリンダの内面とピストンの外面の締り嵌めによる摩擦 力は，常にシリンダとピストンの相対運動を妨げる方向に 作用する。すなわち，ガスクッションカが常にシリンダか 
らピストンを引き出す方向に作用するのに対し, 締り嵌め による摩擦力はシリンダからピストンが引き出される際に は，シリンダにピストンを押し込む方向に（引き出しに抵 抗するように）作用する. 締り嵌めによる摩擦力が，ガス による反発力より小であれば，ピストンを押し込んだとし ても，押し込みを止めれば，ガスクッション力は締り嵌め による摩擦力より大きいので，ピストンはシリンダから引 き出され，押し込み前の元の位置に自動的に戻る，そのた め, 別途, ピストンを戻すための装置等を設ける必要が無 い.また，シリンダとピストンとの間に，ピストンの押し 込みに伴って容積を大きくし，ピストンの引き出しによっ て容積を小さくする空間が形成される。この空間に潤滑油 の吸排口を設け，それぞれの接続口にチェック弁を取り付 けることでポンプとしての機能を持たせることができる.

摩擦クッション部への自己給油機構が構成できるので, 別 途, 嵌合部に潤滑油を供給するためのポンプを設ける必要 が無い. Fig. 6 に自己給油機構の動作図を示す.

合成樹脂や軟質金属などの摩耗しやすい摩擦部材を介在 させず,潤滑油を介在するだけで金属同士が摺動するので, 強い加圧力に対応でき, 耐久性が高い. そして軸部材と穴 とは給油機構から供給される潤滑油を介して摺動し, 摺動 に伴う摩擦熱が潤滑油によって冷却されるので，焼き付き やかじりを生じにくく, 長期にわたって均一な摩擦力を発 揮する.

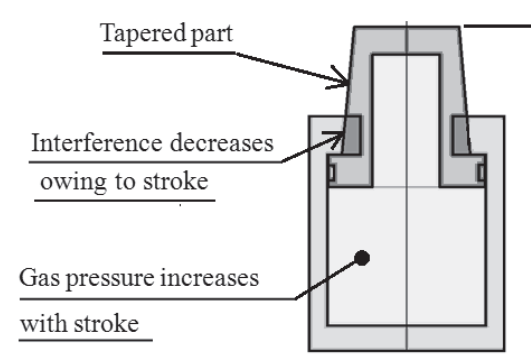

(a) Upper limit of stroke

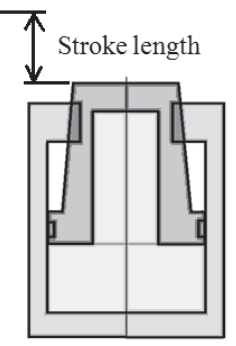

(b) Lower limit of stroke
Fig. 5 Conceptual diagram of friction cushion force

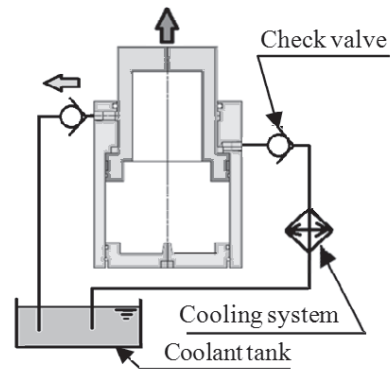

(a) Cooling oil discharge by raising the piston

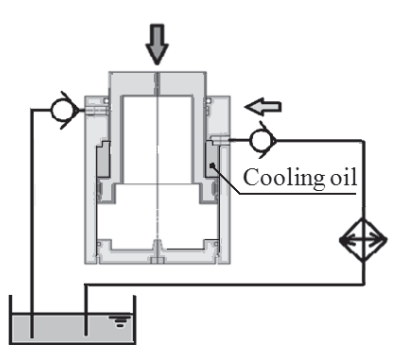

(b) Cooling oil suction by piston lowering
Fig. 6 Operation diagram of self-lubrication mechanism

\section{6. フリクショナルガスクッション装置を適用した 高張力鋼板の成形実験}

\section{1 実験方法}

新工法で $1470 \mathrm{MPa}$ 級の超高張力鋼板の成形をテストす るため，実際に自動車の骨格部品であるフロントピラーの 金型仕様に合わせ, 高能力フリクショナルガスクッション 装置の開発を行った。
製品形状は，今後さらに機能性を持ち，より複雑化する 骨格部品を考慮した形状とし，成形に必要な上部クッショ ン力を得るために, 解析シミュレーションソフト Simufact Forming を使用した.解析に使用した材料の機械的特性を, Table 1 に示す.

Table 1 Mechanical properties

\begin{tabular}{|c|c|c|c|c|}
\hline Standard & Size & Yp [MPa $]$ & Ts〔MPa] & E1〔\%] \\
\hline 1470 & $1.4 \times 300 \times 500$ & 1256 & 1510 & 8 \\
\hline
\end{tabular}

解析条件として，製品の上面にあたるボス部を上部クッ ション力で先行成形し，その後下死点で曲げ加工が完了す るまで，フォーミングパンチとムービングダイが材料を挟 んで常時密着する条件で必要クッション力を解析した. Fig. 7 に, 製品形状と FEM 解析結果を示寸。解析結果より，上 面成形に必要なダイクッション力は $570 \mathrm{kN}$ であった. ボス 成形に均等に荷重伝達ができるように 3 本配置とし，開発 する高能力フリクショナルガスクッション装置概要を

Table 2 に示す.
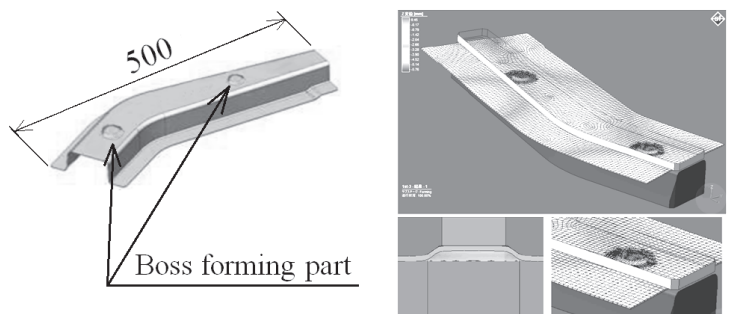

(a) Front pillar forming (b) Condition for consistent sticking of the material between the forming punch and the moving die

Fig. 7 Product shape and FEM analysis result

Table 2 Frictional gas cushion device

\begin{tabular}{|c|c|}
\hline Capacity & $200 \mathrm{kN} \quad$ (All strokes) \\
\hline Stroke length & $45 \mathrm{~mm}$ \\
\hline Nitrogen gas pressure & $14.9 \mathrm{MPa}$ \\
\hline Cylinder length & $200 \mathrm{~mm}$ \\
\hline \multicolumn{2}{|l|}{$<$ Gas cushion part $>$} \\
\hline Outer diameter of piston seal part & $\phi 100 \mathrm{~mm}$ \\
\hline Gas chamber volume at upper limit position & $1126.15 \mathrm{~cm}^{2}$ \\
\hline At initial pressure $14.9 \mathrm{MPa}$ & $117 \mathrm{kN}$ \\
\hline At $45 \mathrm{~mm}$ stroke & $170 \mathrm{kN}$ \\
\hline Compression ratio & $1.46(21.7 \mathrm{MPa})$ \\
\hline \multicolumn{2}{|l|}{$<$ Frictional cushion force part $>$} \\
\hline Cylinder outer diameter $\quad$ (Material: SKD 61) & $\phi 120 \mathrm{~mm}$ \\
\hline Diameter of interference & $\phi 80 \mathrm{~mm}$ \\
\hline Piston inner diameter $\quad$ (Material: SKD 11) & $\phi 56 \mathrm{~mm}$ \\
\hline Fitting length of interference fitting part & $25 \mathrm{~mm}$ \\
\hline Interference at initial position & $0.18 \mathrm{~mm}$ \\
\hline Interference at $45 \mathrm{~mm}$ stroke position & $0.07 \mathrm{~mm}$ \\
\hline
\end{tabular}

式（1），(2）よりクッション能力を一定にするためのス トローク上下限位置での締め代, 発生面圧, 摩擦クッショ ン力を算出した。計算值を Table 3 に示す. 
Table 3 Values used to calculate friction cushion force

\begin{tabular}{|c|r|r|r|}
\hline Stroke length & Interference & $\begin{array}{l}\text { Generated } \\
\text { surface pressure }\end{array}$ & $\begin{array}{l}\text { Frictional } \\
\text { cushion force }\end{array}$ \\
\hline $0 \mathrm{~mm}$ (Upper-limitposition) & $0.18 \mathrm{~mm}$ & $85.6 \mathrm{MPa}$ & $86 \mathrm{kN}$ \\
\hline $45 \mathrm{~mm}$ (Lower-limit position) & $0.07 \mathrm{~mm}$ & $33.3 \mathrm{MPa}$ & $33.5 \mathrm{kN}$ \\
\hline
\end{tabular}

下降時, 上昇時のガスクッション力, 摩擦クッション力 より，トータルクッション力は,

(1) トータルクッション力（下降開始時）：203 kN

(2) トータルクッション力 (下降終了時) : $203.5 \mathrm{kN}$

(3) トータルクッション力 (上昇開始時) : $136.5 \mathrm{kN}$

(4) トータルクッション力（上昇終了時）: $31 \mathrm{kN}$

となる.ガスクッション力, 摩擦クッション力の関係を Fig. 8 に示す.

ピストン摺動部表面の低温 $\mathrm{TiC}$ コーティング処理後の表 面状態, 面粗度, 真円度を Fig. 9 に示す.

シリンダ摺動部表面のラジカル窒化処理前後の表面状態, 面粗度を Fig. 10 に示す.

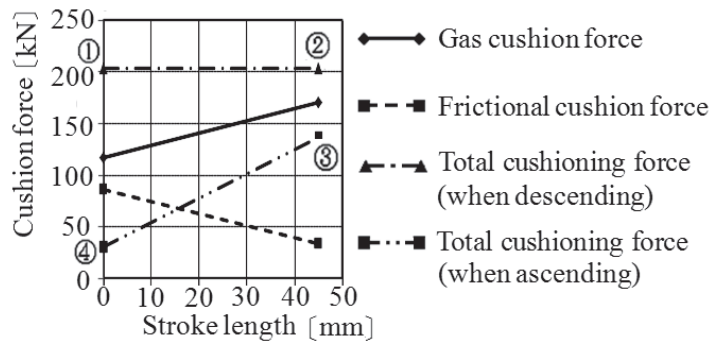

Fig. 8 Total cushioning force

After low-temperature TiC-coating treatment

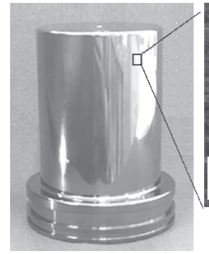

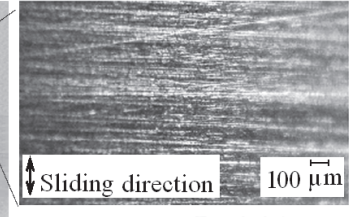

Ra $0.04 \mu \mathrm{m}$

(a) Surface roughness in the sliding direction

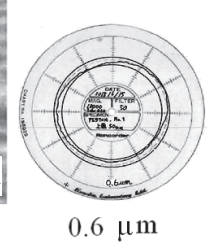

(b) Roundness
Fig. 9 Surface condition of the piston sliding part: surface roughness and roundness

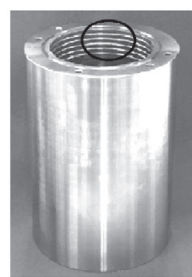

(a) Cylinder

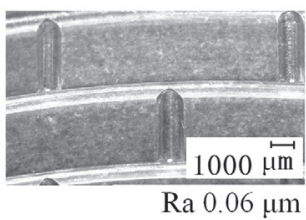

(b) Before radical nitriding treatment

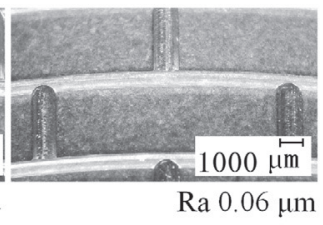

(c) After radical nitriding treatment
Fig. 10 Surface condition of cylinder sliding part: surface roughness

\section{2 結果と考察}

高能力フリクショナルガスクッション装置単体で負荷テ ストを行い，クッションストローク全域のクッション荷重 を測定した. ストローク-トータルクッション力線図を Fig. 11 に示す。計算值と実測值のズレは，プレスフレームの伸
びによるものと推定する. 次に, ストローク中の最大荷重 測定と冷却油作動時のピストンシャフト摺動部付近のシリ ンダ外周温度を温度がサチュレートするまで, 連続して測 定した. Fig. 12 に連続負荷テスト結果を示す.

高能力フリクショナルガスクッション装置単体負荷テス 卜結果より，下降時ではクッションストローク全域にわた りクッションカが一定であった。また，20,000 回の負荷テ ストでも，荷重，温度共に変化はなかった。これは，理論 計算通りにガスクッション力増分と摩擦クッション力減少 分が相殺しているためである. Fig. 13 に高能力フリクショ ナルガスクッション装置と実際の負荷テスト状況を示す。

20,000 回の負荷テスト後にクッション装置を解体し, 締 り嵌め部の表面の観察および面粗度測定を行った結果，シ リンダ並びにピストンの面粗度, 径寸法ともに変化はなく, 摩耗の跡は見られなかった。 Table 4 に, 負荷テスト前後の 測定結果を示す.

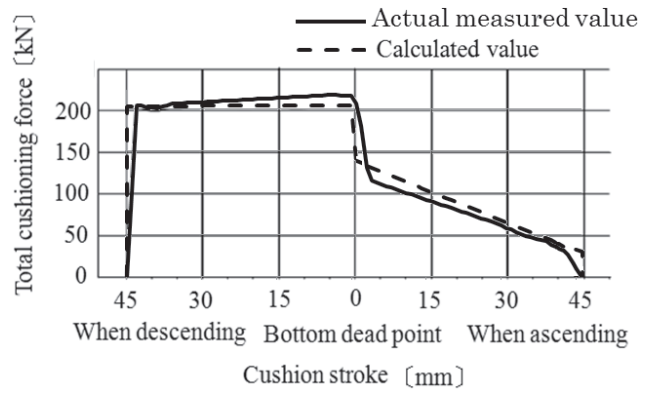

Fig. 11 Stroke-total cushion force diagram

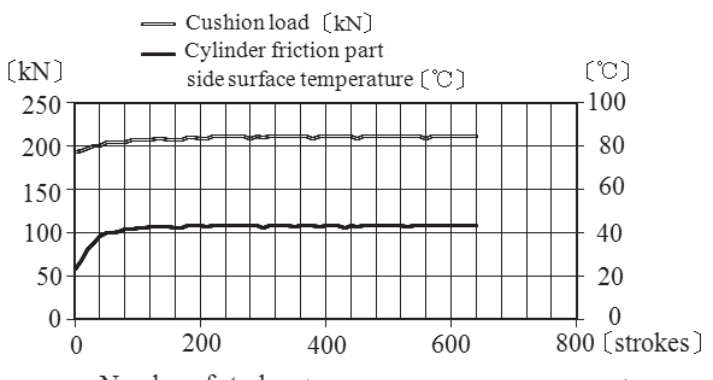

Number of strokes (Continuous load test spm: $15 \mathrm{~min}^{-1}$ )

Fig. 12 Cushion continuous load test
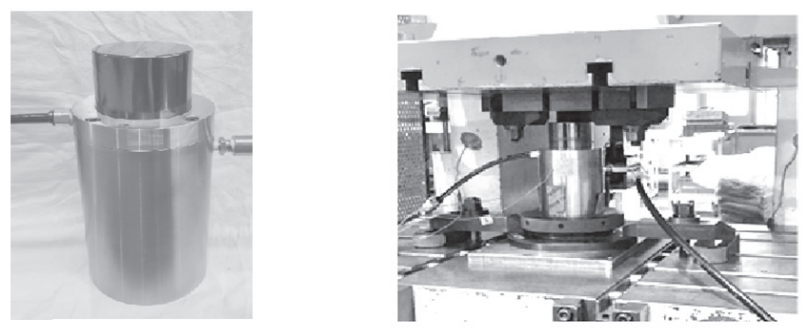

(a) Frictional gas cushion device (b) Actual continuous load test situation

Fig. 13 Load test setup

Table 4 Measurement results before and after load test

\begin{tabular}{|c|c|c|c|}
\hline & \multirow[b]{2}{*}{$\begin{array}{l}\text { Before } 20,000 \\
\text { stroke load test } \\
\end{array}$} & \multirow[b]{2}{*}{$\begin{array}{l}\text { After } 20,000 \\
\text { stroke load test }\end{array}$} \\
\hline & & & \\
\hline \multirow{3}{*}{ Piston } & Surface roughness $[\mu \mathrm{m}]$ & $\mathrm{Ra} 0.04$ & $\mathrm{Ra} 0.04$ \\
\hline & Small-diameter part size $[\mathrm{mm}]$ & $\phi 80.074$ & $\phi 80.074$ \\
\hline & Large-diameter part size $[\mathrm{mm}]$ & $\phi 80.182$ & $\phi 80.182$ \\
\hline \multirow{2}{*}{ Cylinder } & Surface roughness $[\mu \mathrm{m}]$ & Ra 0.06 & Ra 0.06 \\
\hline & Diameter $[\mathrm{mm}]$ & $\phi 79.997$ & $\$ .79 .997$ \\
\hline
\end{tabular}


このように，締め代のある軸部品と穴部品との金属同士 の摺動により摩擦力を発生させる機構は, 高い耐久性と負 荷能力の安定性を有することが実証された.

\section{7. 本装置を使用した製品成形事例}

開発した高能力フリクショナルガスクッション装置を使 用してフロントピラーの成形型を製作してトライを行った. Fig. 14 に高能力フリクショナルガスクッション装置を配 置した $1470 \mathrm{MPa}$ 級の超高張力鋼板成形型の構造を示す.

製品上面成形を先行して行うための可動ダイが，下死点 ではスライドと直接荷重伝達ができる構造になっており, 剛性が確保されている.

次に，一般に市販されている同一能力のガスクッション を高能力クッション使用時と同位置に上型に配置しようと 考えると, ガスクッション装置の外径が大きく干渉するの で配置できず, 所望のクッション力を得ることができない.

またガスクッションの配置の間隔を広げると, 下死点に て，可動ダイとスライドが直接荷重伝達されないので，下 死点での決め押しができず, 製品精度の高精度化が達成で きない. Fig. 15 に一般に市販されている同一能力のガスク ッションを上型配置した構造を示す。

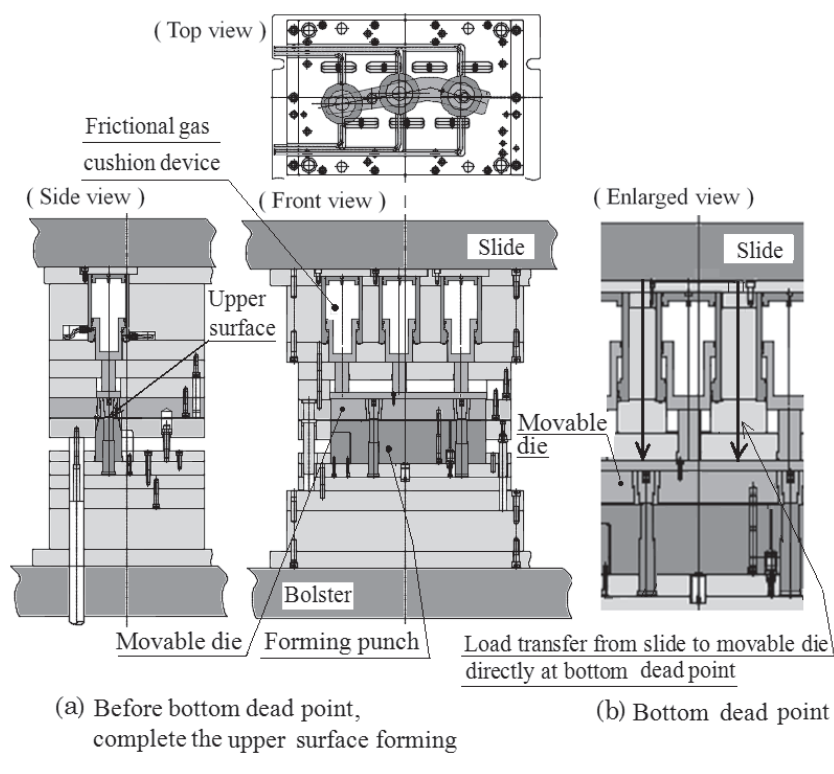

Fig. 14 Ultrahigh-tensile-strength steel plate die structure

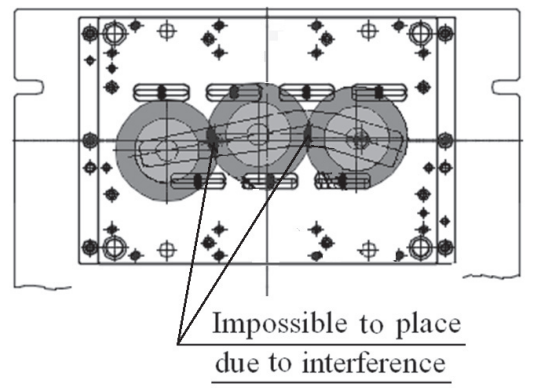

Fig. 15 Problems when using a general gas cushion for the upper die cushion
実際に製作した金型と $1470 \mathrm{MPa}$ 級超高張力鋼板を上面 先行成形まで加工した状態, 成形完了した成形品を Fig. 16 に示す

高能力フリクショナルガスクッション装置にて, 製品の 上面を先行成形することで, 上面のしわの発生を抑制でき， 下死点まで成形することが可能になった。

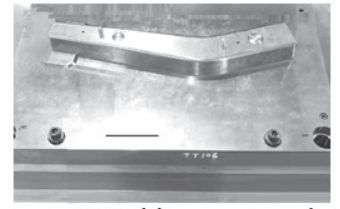

Wrinkle pressing plate (a) Lower die

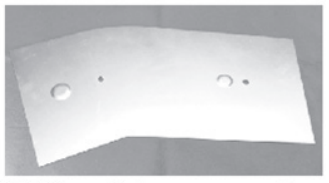

(c) Complete upper surface forming before drawing

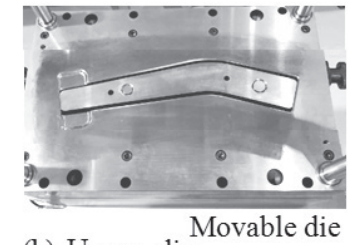

(b) Upper die

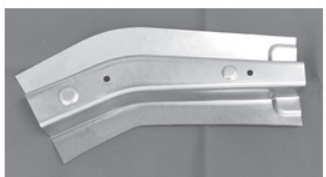

(d) Drawing completed
Fig. 16 1470-MPa-class ultrahigh-tensile-strength steel plate forming process

\section{8. 結 言}

開発した高能力フリクショナルガスクッション装置は, 締め代のある軸部品と穴部品との金属同士の摺動により発 生する摩擦力を応用し, ガスクッションの上部ピストンシ ヤフト部に摩擦力クッション機構を付加したものである.

開発した本装置単体で負荷テストを行ったところ，下降 時ではクッションストローク全域にわたりクッションカが 一定であった。これは，理論計算通りにガスクッション力 増分と摩擦クッション力減少分が相殺しているためである.

また，20,000 回の負荷テストでは，荷重，温度共に変化 がないことが確認された。これらの結果から

（1）金属同士の嵌め合いの締め代を管理することにより, 軸部品と穴部品の摺動による安定した摩擦力を精度良 く得ることができる。

(2) 締め代をストローク中に変化させることで, 摩擦力を 精度良く変更することが可能である.

（3）穴部品の内側と軸部品の外側に摩耗がなく，高い耐久 性が証明された。

(4) ガスクッションに摩擦カクッション機構を付加するこ とで，コンパクトで負荷能力に変化のない高能力ダイ クッション装置が得られる.

この技術を今後も様々な分野に応用し，さらなる技術革 新を推進する。

\section{参 考 文 献}

1) Aida Press Research Group: Want to know Press processing, (1992), 52-70, Japan Machinist Company.

2) JSTP: Sheet Metal Forming, (1994), 55-62, Corona

3) JSME: Mechanical Engineers' Handbook, (1987), A4-73, Maruzen. 